\title{
Properties of a DNA Ligase Mutant of Escherichia coli: Introduction of Strand Breaks in DNA
}

\author{
By C. PAULING, L. A. BECK AND SHARON P. WILCZYNSKI* \\ Department of Biology, University of California, \\ Riverside, California 92502, U.S.A.
}

(Received 5 August 1975; revised 17 November 1975)

\begin{abstract}
SUMMARY
Strand breaks accumulated in the DNA of a temperature-sensitive DNA ligase mutant of Escherichia coli growing at the restrictive temperature, as detected by zone sedimentation through alkaline sucrose density gradients. The rate of strand breakage was increased by concomitant thymine starvation. Rifampicin and chloramphenicol inhibited the accumulation of strand breaks in the DNA. There was a correlation between the accumulation of strand breaks in the DNA and lethality, suggesting that such breaks are the basis for lethality at the restrictive temperature.
\end{abstract}

\section{INTRODUCTION}

Indirect evidence suggests that bacterial DNA sustains repairable lesions as a consequence of normal metabolic processes. Much of the evidence comes from studies on thymineless death (Barner \& Cohen, 1954, 1957). It has been argued that the pathological effects of thymine starvation are due to the accumulation of strand breaks in the DNA, produced during normal cell metabolism, which cannot be repaired in the absence of thymine (Hanawalt, 1963; Pauling \& Hanawalt, 1965; Nakayama \& Hanawalt, 1975), and, specifically, that transcription may result in strand breaks. Such breaks may be repaired directly by DNA ligase; however, if nuclease activity converts a strand break into a strand gap, DNA synthesis would be required for repair, and DNA synthesis is inhibited in the absence of thymine.

If strand breaks occur in DNA as a consequence of normal metabolic processes, one important function of DNA repair in unirradiated cells may be to restore the continuity of the DNA strands following the production of such breaks. In order to obtain evidence relating to the role of DNA repair in the normal metabolism of bacterial cells, we isolated a temperature-sensitive mutant of $E$. coli defective in the enzyme DNA ligase (Pauling \& Hamm, I968, 1969). This mutant strain has increased sensitivity both to irradiation with ultraviolet light and X-rays, and to thymine starvation, relative to its parent strain (Pauling \& Hamm, 1968; Dean \& Pauling, 1970). It accumulates Okazaki fragments of newlyreplicated DNA upon incubation at the restrictive temperature (Pauling \& Hamm, I969). These results indicate an involvement of DNA ligase both in repair of DNA of irradiated cells and in semi-conservative replication of DNA. The mutant also shows an increased sensitivity to mild heating, and an increased accumulation of strand breaks in DNA following mild heating (Paulingl\& Beck, 1975). If strand breaks are induced in DNA as a consequence of the normal metabolic processes of the cell, incubation of the DNA

\footnotetext{
* Present address: Department of Microbiology and Immunology, University of California, Los Angeles, California 90024, U.S.A. 
ligase-defective strain at the restrictive temperature should result in the accumulation of such breaks. We have examined the DNA from the DNA ligase-defective mutant for strand breaks, by zone sedimentation through alkaline sucrose density gradients, following growth at the restrictive temperature both in the presence and absence of exogenous thymine. We present evidence in this paper that strand breaks do accumulate in the DNA during growth at the restrictive temperature, and that the accumulation of such breaks is inhibited by rifampicin and low levels of chloramphenicol, agents that also spare the cells from the lethality observed upon growth at the restrictive temperature (Pauling \& Hamm, I968).

\section{METHODS}

Organisms and culture conditions. Escherichia coli TAU-bar, a polyauxotrophic derivative of $E$. coli 15T $^{-}$(Hanawalt, 1963), and ts7, a temperature-sensitive DNA ligase-defective derivative of TAU-bar (Pauling \& Hamm, 1968), were cultured aerobically in a glucosesalts minimal medium with appropriate supplements (Deutch \& Pauling, 1971). Media transfers were accomplished by centrifugation. Viable counts were determined by plating appropriate dilutions on an enriched medium as described previously (Deutch \& Pauling, 1971).

Labelling procedures. Exponential-phase cultures ( $10 \mathrm{ml}$ ) were grown at $25^{\circ} \mathrm{C}$ to a density of $1 \times 10^{8}$ cells $/ \mathrm{ml}$ in minimal medium supplemented with the required growth factors including $0.5 \mu \mathrm{g}$ thymine $/ \mathrm{ml}$ and either $200 \mu \mathrm{Ci}$ [methyl ${ }^{3} \mathrm{H}$ ] thymine (New England Nuclear; Io $\mathrm{Ci} / \mathrm{mm}$ ) or $10 \mu \mathrm{Ci}\left[2-{ }^{14} \mathrm{C}\right]$ thymine (Schwarz-Mann; $56 \mathrm{mCi} / \mathrm{mm}$ ). The cultures were harvested, washed with unsupplemented minimal medium, and resuspended in an equal volume of fresh medium. Appropriate supplements were added and the cultures incubated under the conditions described.

Detection of single strand breaks in DNA. Samples were removed and the DNA assayed for strand breaks by zone sedimentation through alkaline sucrose density gradients using a modification (Kato \& Kondo, 1970; Sedgwick \& Bridges, 1972) of the method of McGrath \& Williams (I966). After sampling, ${ }^{3} \mathrm{H}$-labelled ts7 cells and ${ }^{14} \mathrm{C}$-labelled TAU-bar cells were mixed together, and $0.3 \mathrm{ml}$ of the mixed suspension was added to $0.6 \mathrm{ml}$ of a solution containing $1 \%(\mathrm{w} / \mathrm{v})$ sodium dodecyl sulphate, $0.25 \mathrm{M}-\mathrm{NaOH}, 0.005 \mathrm{M}-\mathrm{EDTA}, 0.05 \mathrm{M}-\mathrm{NaCl}$, and $0.005 \mathrm{M}$-tris(hydroxymethyl)aminomethane (Trizma Base; Sigma) that had been previously layered on the top of a $36 \mathrm{ml} 5$ to $20 \%$ linear sucrose density gradient containing $0.1 \mathrm{M}-\mathrm{NaOH}, 0.9 \mathrm{M}-\mathrm{NaCl}$, and $0.00 \mathrm{I} \mathrm{M}-\mathrm{EDTA}, \mathrm{pH}$ II.5. A period of $20 \mathrm{~min}$ was allowed for lysis, then the gradients were centrifuged in an SW-27 rotor in a Beckman L2-65B centrifuge at $27000 \mathrm{rev} . / \mathrm{min}$ for $2 \mathrm{~h}$ at $20^{\circ} \mathrm{C}$. Ten-drop fractions were collected from the bottom of the centrifuge tube and assayed for radioactivity as previously described (Pauling \& Hamm, 1968).

\section{RESULTS}

Prelabelled DNA was assayed for strand breaks by zone sedimentation. Figure I presents sedimentation profiles for DNA from TAU-bar and ts7 following 0, 40, 80 and I $20 \mathrm{~min}$ growth at $40{ }^{\circ} \mathrm{C}$. The profiles for TAU-bar show no increase in the number of strand breaks during this period. However, the profiles for ts 7 show a steady decrease in the sedimentation rate for the single-stranded DNA with increasing time of incubation at $40{ }^{\circ} \mathrm{C}$; this indicates an accumulation of strand breaks in the DNA.

Walker (1970), Reichenbach, Schaiberger \& Sallman (I97I), and Nakayama \& Hanawalt (1975) have presented evidence that chromosomal DNA sustains strand breaks during thymine starvation. Since ts7 shows a marked increase in sensitivity to thymine starvation 


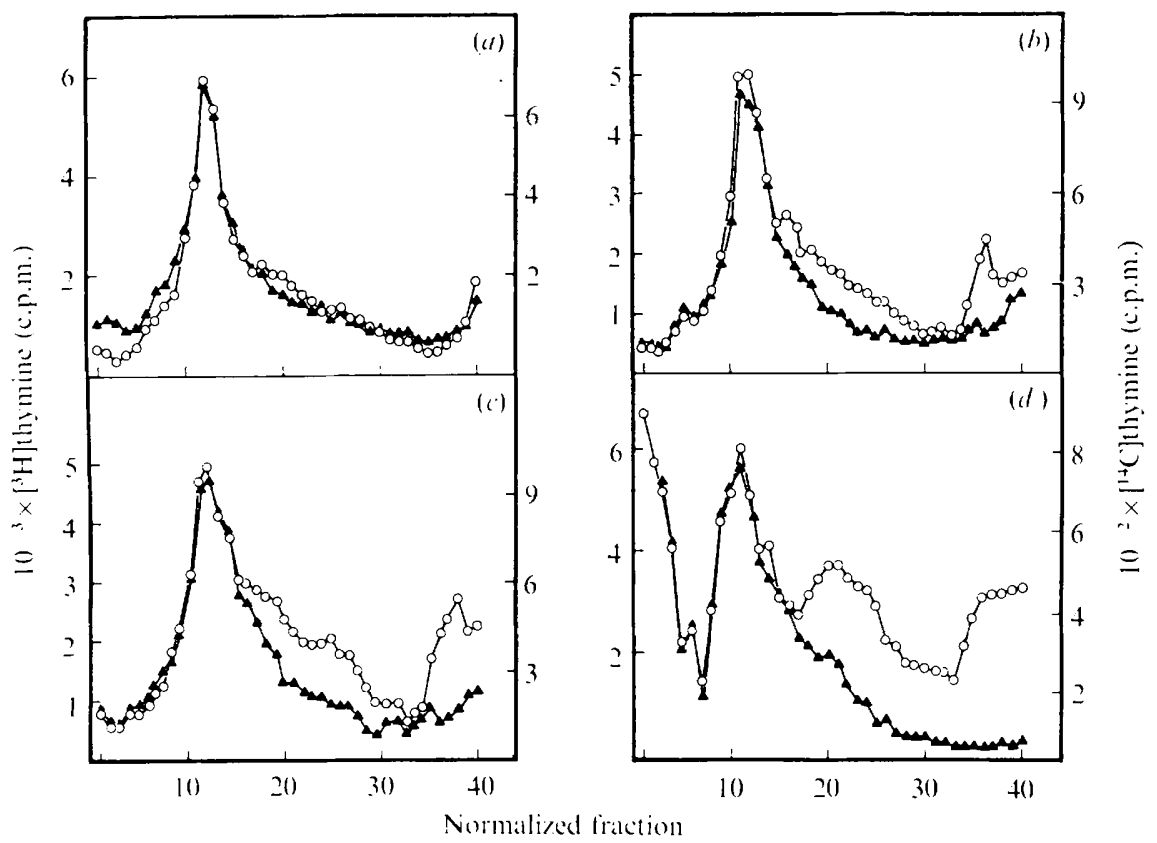

Fig. I. Sedimentation profiles of TAU-bar $(\Delta)$ and ts $7(O)$ DNA following growth at $40^{\circ} \mathrm{C}$. $\left[{ }^{14} \mathrm{C}\right]$ thymine-labelled TAU-bar and $\left[{ }^{3} \mathrm{H}\right]$ thymine-labelled ts7 cells were incubated at $40^{\circ} \mathrm{C}$ for (a) $0 \mathrm{~min},(b) 40 \mathrm{~min},(c) 80 \mathrm{~min}$, and (d) $120 \mathrm{~min}$.

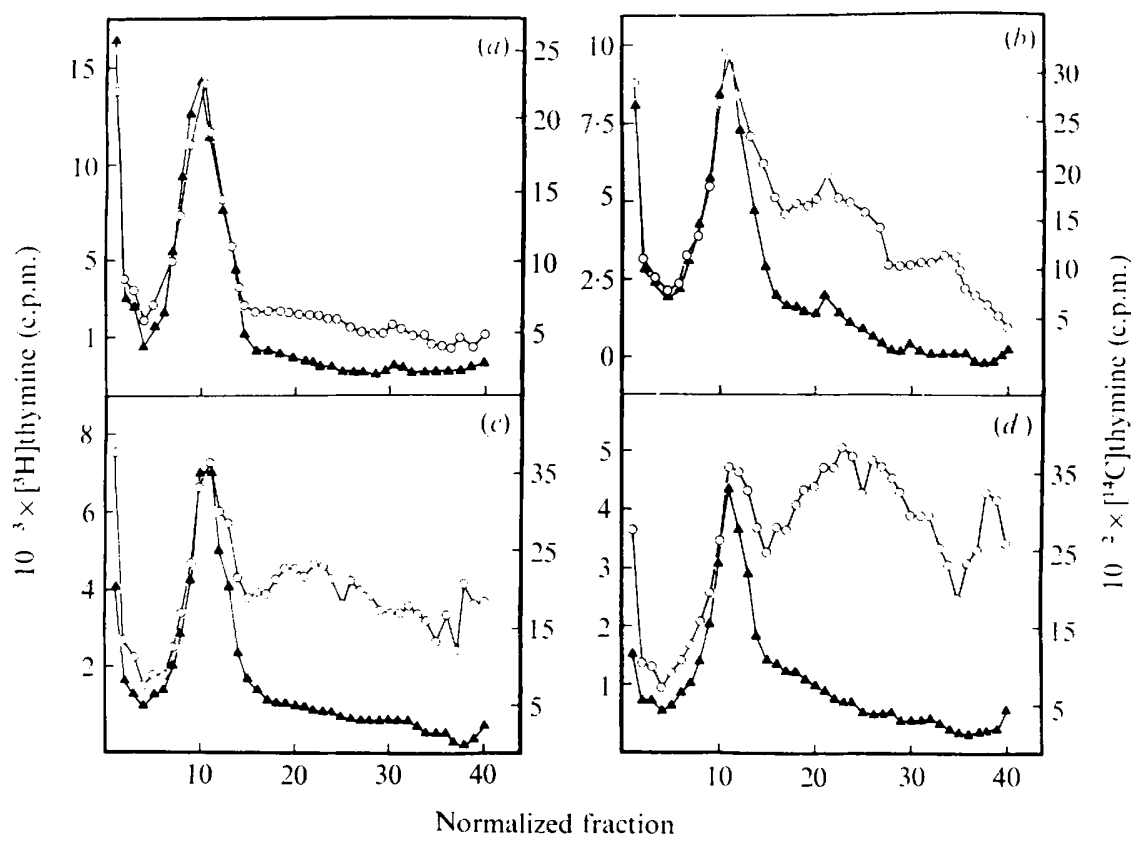

Fig. 2. Sedimentation profiles of TAU-bar $(\Delta)$ and ts7 $(O)$ DNA following thymine starvation at $40^{\circ} \mathrm{C}$. $\left[{ }^{14} \mathrm{C}\right]$ thymine-labelled TAU-bar and $\left[{ }^{3} \mathrm{H}\right]$ thymine-labelled ts 7 cells were incubated in minimal medium lacking thymine at $40^{\circ} \mathrm{C}$ for $(a)$ o min, (b) $40 \mathrm{~min},(c) 80 \mathrm{~min}$, and $(d) 120 \mathrm{~min}$. 


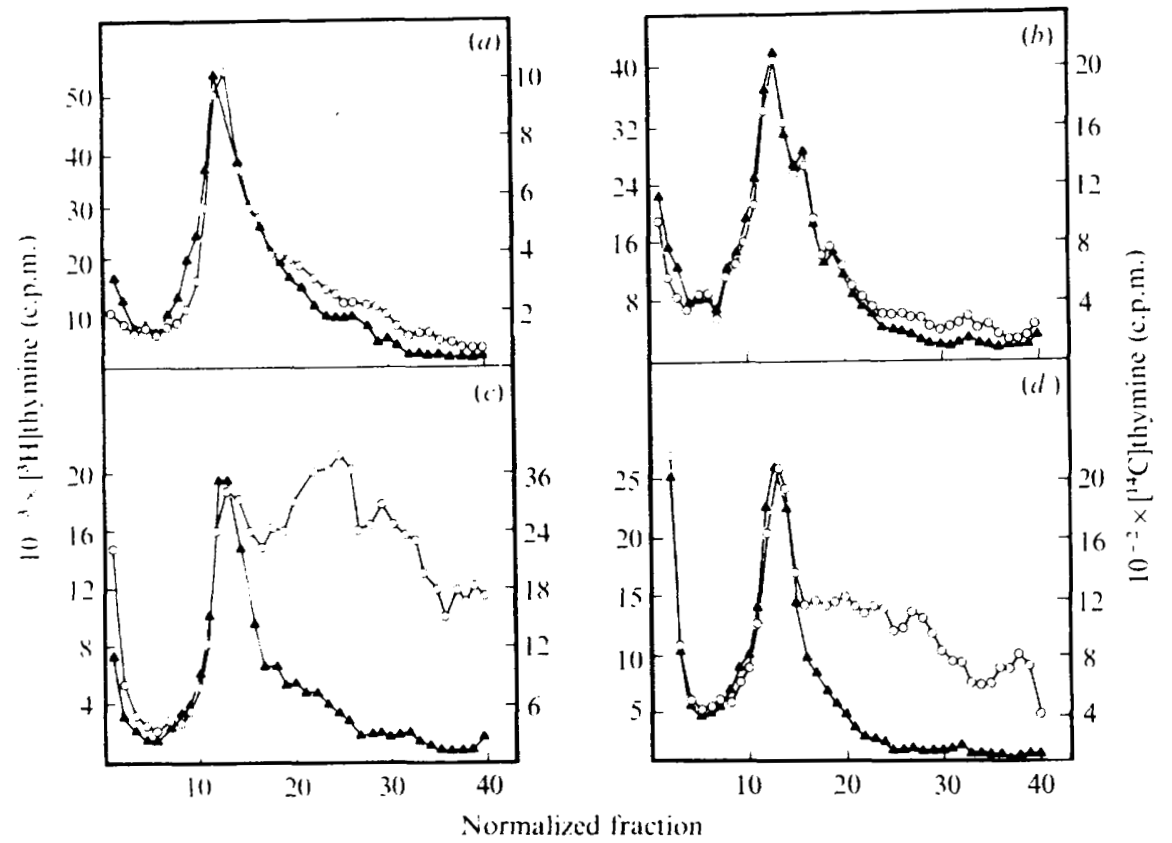

Fig. 3. Sedimentation profiles of TAU-bar $(\boldsymbol{\Delta})$ and ts7 $(O)$ DNA after temperature shift. $\left[{ }^{14} \mathrm{C}\right]$ thymine-labelled TAU-bar and [ $\left.{ }^{3} \mathrm{H}\right]$ thymine-labelled ts7 cells were incubated as indicated, and the sedimentation profiles of the DNA were determined. (a) No incubation; (b) 120 min at $25^{\circ} \mathrm{C}$ with thymine; (c) 120 min at $40^{\circ} \mathrm{C}$ without thymine; (d) $120 \mathrm{~min}$ at $40^{\circ} \mathrm{C}$ without thymine, followed by $\mathrm{I} 20 \mathrm{~min}$ at $25^{\circ} \mathrm{C}$ with thymine.

at the restrictive temperature (Pauling \& Hamm, 1968), it is expected that thymine starvation should enhance the accumulation of strand breaks in the DNA upon growth at the restrictive temperature. Figure 2 presents sedimentation profiles for DNA from TAU-bar and ts 7 following $0,40,80$ and 120 min incubation in the absence of thymine at $40{ }^{\circ} \mathrm{C}$. The profiles for TAU-bar again provide no indication of an increase in the number of strand breaks during this period; however, the profiles for ts 7 indicate that there is a marked increase in the accumulation of strand breaks in the DNA under these conditions.

If a normal function of DNA ligase is to repair strand breaks arising from normal metabolic processes, it should be possible to demonstrate the repair of the strand breaks by simultaneously reintroducing thymine and returning the culture to the permissive temperature. Figure 3 indicates the sedimentation profiles obtained for TAU-bar and ts 7 DNA following $120 \mathrm{~min}$ thymine starvation at $40^{\circ} \mathrm{C}, 120 \mathrm{~min}$ growth in the presence of thymine at $25^{\circ} \mathrm{C}$, and 120 min thymine starvation at $40^{\circ} \mathrm{C}$ followed by 120 min growth at $25^{\circ} \mathrm{C}$ in the presence of thymine. Again, the sedimentation profiles for TAU-bar DNA show no significant deviation from that of the 0 min control. The profiles for ts 7 DNA are consistent with the expectation that there is substantial repair of breaks during a period of growth at the permissive temperature. We have not observed the repair of strand breaks that accumulate upon growth at the restrictive temperature in the presence of thymine.

The demonstration that strand breaks accumulated in prelabelled DNA under conditions of thymine deprivation at $40{ }^{\circ} \mathrm{C}$ leads to speculation concerning the cause of such breaks. It has been suggested that RNA synthesis, and in particular mRNA synthesis, is required for the deleterious effects of thymine starvation to be expressed (Hanawalt, I963; Pauling \& 

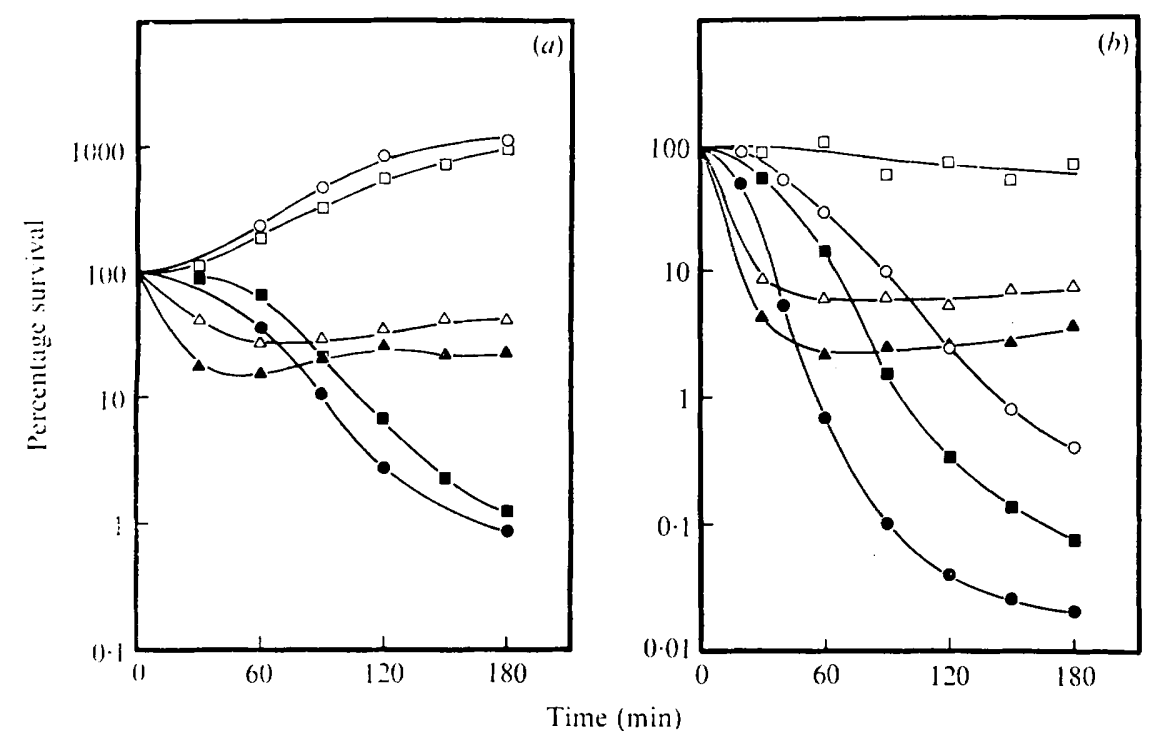

Fig. 4. Effect of rifampicin and chloramphenicol on survival. Cultures of (a) TAU-bar and (b) ts7 were grown to a density of $10^{8}$ cells $/ \mathrm{ml}$ at $25^{\circ} \mathrm{C}$, harvested, washed twice with unsupplemented medium, and resuspended in fresh medium with and without thymine. The cultures were divided; no additional supplements were added to one portion, $200 \mu \mathrm{g}$ rifampicin/ml was added to a second, and $3 \mu \mathrm{g}$ chloramphenicol $/ \mathrm{ml}$ to the third. The cultures were incubated at $40^{\circ} \mathrm{C}$, and the viable count determined at intervals. $O$, + Thymine; - - thymine; $\square$, +thymine + chloramphenicol; $\boldsymbol{\square},-$ thymine + chloramphenicol; $\Delta$, +thymine + rifampicin; $\boldsymbol{\Delta},-$ thymine + rifampicin.

Hanawalt, 1965; Nakayama \& Hanawalt, 1975). Accordingly, thymine starvation in the presence of rifampicin, which inhibits the initiation of RNA synthesis, should result in increased survival. Figure 4 presents survival of TAU-bar and ts 7 following growth in the presence and absence of thymine at $40{ }^{\circ} \mathrm{C}$ in media without antibiotic, with $200 \mu \mathrm{g}$ rifampicin (RIF)/ml, and with $3 \mu \mathrm{g}$ chloramphenicol (CAM) $/ \mathrm{ml}$. These data indicate that although both TAU-bar and ts7 are sensitive to RIF, in that they both sustain loss of viability upon incubation in medium supplemented with RIF, the addition of RIF spares some of the cells from the lethality of growth at the restrictive temperature both in the presence and absence of thymine. This sparing is manifested in the similarity of the survival curves of both strains upon incubation in medium supplemented with RIF. Incubation of the cells in medium supplemented with $3 \mu \mathrm{g} \mathrm{CAM} / \mathrm{ml}$ had a surprising effect. This low concentration of CAM had little effect on the survival of TAU-bar upon growth in the presence or absence of thymine over the period tested. Incubation of ts 7 at the restrictive temperature in medium supplemented with $3 \mu \mathrm{g} \mathrm{CAM} / \mathrm{ml}$ resulted in a complete sparing of the lethality associated with growth at the restrictive temperature, and some amelioration of thymineless death. This concentration of CAM had no detectable effect on the rate of incorporation of $\left[{ }^{3} \mathrm{H}\right]$ uracil and $\left[{ }^{14} \mathrm{C}\right]$ arginine into acid-precipitable material over a $120 \mathrm{~min}$ period.

Since RIF ameliorates the lethal effects of thymine starvation, and CAM spares ts 7 from death upon growth at the restrictive temperature, we examined sedimentation profiles of prelabelled DNA from TAU-bar and ts7 cells grown at $40{ }^{\circ} \mathrm{C}$ in the presence (Fig. 5) and absence (Fig. 6) of thymine with and without $200 \mu \mathrm{g} \mathrm{RIF} / \mathrm{ml}$ and $3 \mu \mathrm{g} \mathrm{CAM} / \mathrm{ml}$. The data indicate that the accumulation of strand breaks in the DNA is inhibited by these antibiotics. This effect was not due to a restoration of DNA ligase activity by these antibiotics; 

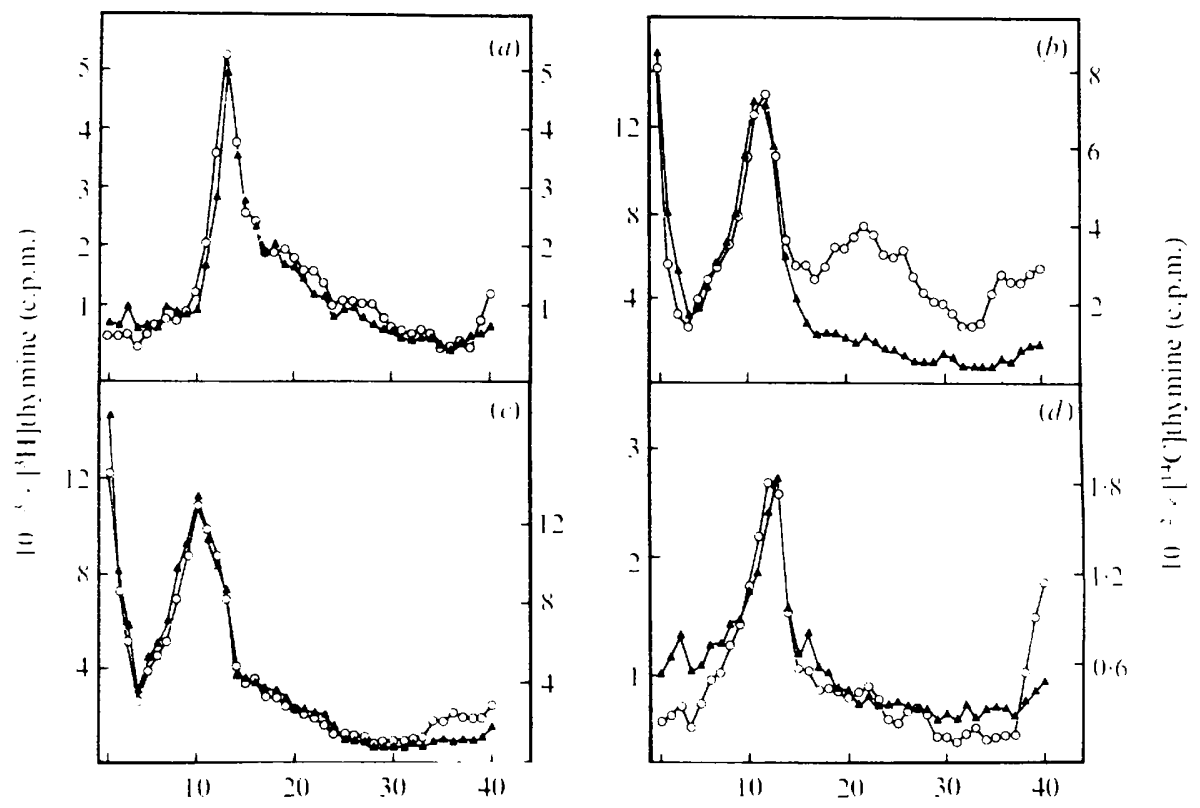

Normalized fraction

Fig. 5. Effect of rifampicin and chloramphenicol on sedimentation profiles of tAU-bar $(\boldsymbol{\Delta})$ and ts7 (O) DNA following growth at $40{ }^{\circ} \mathrm{C}$. $\left[{ }^{14} \mathrm{C}\right]$ thymine-labelled TAU-bar and $\left[{ }^{3} \mathrm{H}\right]$ thymine-labelled ts7 cells were incubated as indicated. (a) No incubation; (b) $120 \mathrm{~min}$ at $40^{\circ} \mathrm{C} ;(c) 120 \mathrm{~min}$ at $40^{\circ} \mathrm{C}$ with $3 \mu \mathrm{g}$ chloramphenicol $/ \mathrm{ml} ;(d)$ I 20 min at $40^{\circ} \mathrm{C}$ with $200 \mu \mathrm{g}$ rifampicin $/ \mathrm{ml}$.

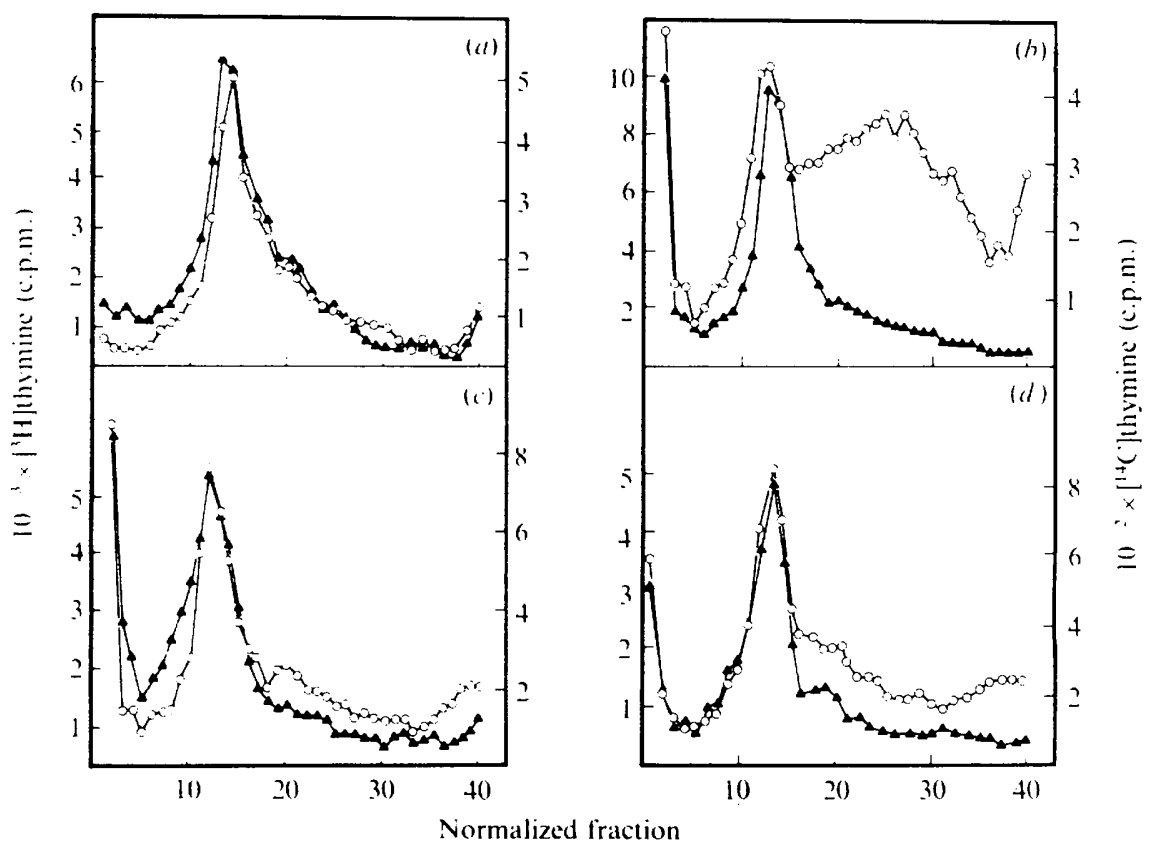

Fig. 6. Effect of rifampicin and chloramphenicol on sedimentation profiles of TAU-bar $(\mathbf{\Delta})$ and ts7 (O) DNA following thymine starvation. $\left[{ }^{14} \mathrm{C}\right]$ thymine-labelled TAU-bar and $\left[{ }^{3} \mathrm{H}\right]$ thyminelabelled ts7 cells were incubated as indicated. (a) No incubation; $(b)$ I 20 min at $40^{\circ} \mathrm{C}$ without thymine; (c) I $20 \mathrm{~min}$ at $40^{\circ} \mathrm{C}$ without thymine and with $3 \mu \mathrm{g}$ chloramphenicol $/ \mathrm{ml} ;(d)$ I $20 \mathrm{~min}$ at $40^{\circ} \mathrm{C}$ without thymine and with $200 \mu \mathrm{g}$ rifampicin $/ \mathrm{ml}$. 
the accumulation of Okazaki fragments of newly-replicated DNA characteristic of ts7 (Pauling \& Hamm, 1969) is not affected by these antibiotics at the concentrations used. Thus we interpret the effect of both $200 \mu \mathrm{g} \mathrm{RIF} / \mathrm{ml}$ and $3 \mu \mathrm{g} \mathrm{CAM} / \mathrm{ml}$ as inhibiting the introduction of the strand breaks in the DNA, and not as enhancing their repair.

\section{DISCUSSION}

We have presented evidence that strand breaks accumulate in chromosomal DNA of the temperature-sensitive DNA ligase-deficient mutant of $E$. coli, upon growth at the restrictive temperature both in the presence and absence of exogenous thymine. A causal relationship between RNA synthesis and thymineless death has been suggested (Hanawalt, 1963; Pauling \& Hanawalt, 1965; Nakayama \& Hanawalt, 1975). The number of strand breaks which escape repair in the normal strain is insufficient to be detected by the methods used here. Under conditions of thymine starvation when DNA ligase activity is absent, such strand breaks accrue and are not repaired, resulting in an enhanced sensitivity to thymineless death. The observation that lethality and the accumulation of strand breaks were both inhibited by RIF is consistent with the postulated role of RNA synthesis in thymineless death, and with the suggestion that single strand breaks accompany RNA synthesis.

The inhibition of the accumulation of strand breaks in DNA by CAM both in the presence and absence of thymine, even though RNA and protein synthesis continued, indicates that some function which results in strand breaks is inhibited by $3 \mu \mathrm{g} \mathrm{CAM} / \mathrm{ml}$. However, the observation that $3 \mu \mathrm{g} \mathrm{CAM} / \mathrm{ml}$ spared the DNA ligase-deficient cells from death at the restrictive temperature in the presence of thymine, but did not markedly affect survival under thymineless conditions, suggests that different molecular events occur upon growth at $40^{\circ} \mathrm{C}$ in the presence of thymine from those that occur in the absence of thymine. This is also suggested by the observation that the strand breaks produced by incubation at $40^{\circ} \mathrm{C}$ in the presence of thymine were not repairable, whereas a large proportion of the strand breaks produced by incubation at $40^{\circ} \mathrm{C}$ in the absence of thymine were repairable. These results indicate that two types of strand breaks may be produced at the restrictive temperature in the absence of thymine, one of which is repairable and the other not, and that the type that is not repairable is possibly similar to that produced in the presence of thymine. From the data presented in Figs. 5 and 6 it is apparent that CAM inhibits formation of all strand breaks in the presence of thymine, but only partially inhibits formation of strand breaks in the absence of thymine. The differential effects of CAM, therefore, could be the consequence of the types of lesions formed at $40^{\circ} \mathrm{C}$ in the presence and absence of thymine, with CAM specifically inhibiting the formation of the non-repairable lesions.

During growth in the presence of thymine at $40{ }^{\circ} \mathrm{C}$ the DNA ligase-deficient strain continued to synthesize DNA. However, Okazaki fragments of newly-replicated DNA accumulate (Pauling \& Hamm, I969). This results in the accumulation of double-stranded DNA containing frequent single-stranded gaps along one strand. Under thymineless conditions, however, DNA synthesis is arrested; accordingly, Okazaki fragments do not accumulate. We propose that the lethal event for DNA ligase-deficient cells growing at the restrictive temperature in the presence of thymine is a double strand break resulting from an endonucleolytic attack of the intact strand opposite a gap between Okazaki fragments. The endonuclease activity of exonuclease $\mathrm{V}$ has precisely the specificity required to convert a single strand gap to a double strand break (Goldmark \& Linn, 1972; Karu et al., 1973). This hypothesis leads to the prediction that the endonuclease activity of exonuclease $\mathrm{V}$ is sensitive to $3 \mu \mathrm{g} \mathrm{CAM} / \mathrm{ml}$. 
We thank Dr P. R. Painter and L. S. Morse for helpful discussion and comments on the manuscript. This work was supported by Public Health Service grant AI-07798 from the National Institute of Allergy and Infectious Diseases.

\section{REFERENCES}

BARNER, H. D. \& COHEN, S. S. (1954). Induction of thymine synthesis by T2 infection of a thymine requiring mutant of Escherichia coli. Journal of Bacteriology 68, 80-88.

Barner, H. D. \& CChen, S. S. (1957). The isolation and properties of amino acid requiring mutants of a thymineless bacterium. Journal of Bacteriology 74, 350-355.

Dean, C. \& Pauling, C. (1970). Properties of a deoxyribonucleic acid ligase mutant of Escherichia coli: X-ray sensitivity. Journal of Bacteriology 102, 588-589.

Deutch, C. E. \& Pauling, C. (197I). Survival and macromolecular synthesis during incubation of Escherichia coli in limiting thymine. Journal of Bacteriology 106, 197-203.

Goldomark, P. J. \& LinN, S. (1972). Purification and properties of the recBC DNase of Escherichia coli K-I 2. Journal of Biological Chemistry 247, 1849-1860.

HaNAWALt, P. C. (1963). Involvement of synthesis of RNA in thymineless death. Nature, London 198, 286.

Karu, A. E., MacKay, V., Goldmark, P. J. \& LinN, S. (1973). The recBC deoxyribonuclease of Escherichia coli $\mathrm{K}$-I 2: substrate specificity and reaction intermediates. Journal of Biological Chemistry 248, 48744884 .

Kato, T. \& Kondo, S. (1970). Genetic and molecular characteristics of X-ray sensitive mutants of Escherichia coli defective in repair synthesis. Journal of Bacteriology 104, 871-88I.

MCGrath, R. A. \& Williams, R. W. (1966). Reconstruction in vivo of irradiated Escherichia coli deoxyribonucleic acid: the rejoining of broken pieces. Nature, London 212, 534-535.

Nakayama, H. \& Hanawalt, P. (1975). Sedimentation analysis of deoxyribonucleic acid from thyminestarved Escherichia coli. Journal of Bacteriology 121, 537-547.

PaUling, C. \& BeCK, L. A. (1975). Role of DNA ligase in the repair of single strand breaks induced in DNA by mild heating of Escherichia coli. Journal of General Microbiology 87, I8I-184.

PAuling, C. \& HaMm, L. (1968). Properties of a temperature sensitive radiation sensitive mutant of Escherichia coli. Proceedings of the National Academy of Sciences of the United States of America 60, 1495-1 502.

Pauling, C. \& Hamm, L. (1969). Properties of a temperature-sensitive, radiation-sensitive mutant of Escherichia coli. II. DNA replication. Proceedings of the National Academy of Sciences of the United States of America 64, I 195-I 202.

Pauling, C. \& Hanawalt, P. (1965). Nonconservative DNA replication in bacteria after thymine starvation. Proceedings of the National Academy of Sciences of the United States of America 54, 1728-1735.

Reichendach, D. L., Schaiberger, G. E. \& Sallman, B. (197I). The effect of thymine starvation on chromosomal structure of Escherichia coli JG-15I. Biochemical and Biophysical Research Communications 42, 23-29.

SEDGWICK, S. G. \& BRIDGes, B. R. (1972). Evidence for indirect production of DNA strand scissions during mild heating of Escherichia coli. Journal of General Microbiology 71, I91-193.

WALKER, J. R. (1970). Thymine starvation and single breaks in chromosomal deoxyribonucleic acid of Escherichia coli. Journal of Bacteriology 104, 139 I-1 392. 